\title{
A Note on Names and Spelling
}

I have attempted to modernize all Portuguese personal names, while refraining from the Anglo-American practice of citing Portuguese by their last name only, when a multiple name is preferred. Wherever practical, I have rendered African names in a standard Bantu form, but in most cases I have simply adopted the most common contemporary Portuguese spelling. For example I prefer Makua to Macua, Lomwe to Lomue, Lujenda to Lugenda, but retain Mauruça and Uticulo in the absence of a more widely recognized Bantu spelling. I have also chosen to reserve use of the name Maravi for the peoples who compose that socio-linguistic group, while using that of Malawi for the modern state only. And I have preferred Nyasa to Malawi for the name of the lake, since that is the name by which it was known to most people during the period of this study. Somewhat differently motivated is my decision to employ the name Zimbabwe for the white minority ruled territory presently known as Rhodesia. The famous stone ruins located near the town of Fort Victoria are distinguished as Great Zimbabwe. A finer point concerns my retention of the convenient term prazero, which $\mathrm{M}$. D. D. Newitt points out in an appendix to his major study of Portuguese Settlement on the Zambesi does not exist in the Portuguese language. Finally, since positional inheritance was an important feature of traditional political structure in the societies of East Central Africa, I have always given the titular names of chiefs as 'the Lundu' or 'the Mucutomuno', unless a personal or any other distinguishing name is also given, as in 'Kalonga Muzura' or 'Mwene Mutapa Gatsi Rusere'. 